\title{
Representations of Language Identity in Today’s Gallo Community
}

\author{
Cécile H. C. Rey \\ University of Virginia, USA
}

\begin{abstract}
This study focuses on the representations of the Gallo language spoken in the Eastern part of Brittany among older speakers (group 1-41 informants) and students of Gallo (group 2-17 informants). Jones and Singh (2005) stress the importance of an asserted community identity for language transmission and the involvement of community members in the revitalization process. The present research establishes that, in order to obtain a more appropriate and possibly successful revitalization program, it is necessary to consult and probe the approval of native speakers of Gallo. Informants from both groups show little involvement in language planning activities; in contrast, revitalization efforts in the last decades have increased within associative and militant groups. The results of field research on language attitudes show a positive Gallo identity. Only 20\% of group 1 and $21.4 \%$ of group 2 declared that Gallo was not an important part of their identity, and more than $80 \%$ of the informants think that the knowledge of Gallo is an advantage. This research demonstrates that the speech community expresses a more positive Gallo identity than expected, one of the main factors necessary to secure language maintenance.
\end{abstract}

Keywords: language identity, representations, language transmission, language preservation, language planning

\section{Introduction}

Brittany is composed of two main regions, Haute-Bretagne (Bretagne romane, Bretagne Gallo) and Basse-Bretagne (Bretagne bretonnante). The distinction is a linguistic one since it reflects the linguistic separation between the two geographical areas. Basse-Bretagne corresponds to the Breton area (Brezhoneg in the Celtic language) and Haute-Bretagne is the region where Gallo varieties are still used. According to previous studies, Nolan (2008b), and Blanchet and Le Coq (2007), Gallo speakers did not express positive representations of the language and culture of Haute-Brittany.

This study presents the framework of the survey inspired from Jones \& Singh's study (2005) on Jèrriais Norman French and show whether a successful language planning can lead to revitalization. This research also exposes the methodology, data-collection, and questionnaires followed by the analysis and results on identity and representations. The discussion section enlarges the topic to explore identity and transmission as a key to language maintenance.

\section{Framework}

Three organizations are working on the maintenance of the Gallo language: Bertaeyn Galeizz (1976), Chubri, and Dastum. Members devote most of their time collecting recordings of songs, readings of texts,

Cécile H. C. Rey, Ph.D., French Department, University of Virginia. 
stories, legends, and toponymy organize social events, working with other organizations on literature and lexicon related to environment, biology and traditions as "devising ways to raise the public awareness and learning about local customs" (Jones, 2001, p. 74). Chubri is involved in creating and providing a new graphic system in Gallo. Bertaeyn Galeizz and Dastum function as databases for researchers, teachers, and scholars who are working on the language.

When comparing the situation of Jèrriais and Gallo, we find similar issues and concerns in both linguistic communities.

\section{Profile of the Jèrriais Speech Community}

Jones used a three-part interview with one set of informants (50 adults) who answered a sociolinguistic questionnaire and a lexical questionnaire followed by a tape-recorded conversation. Jones used the "friend-of-a friend" technique ${ }^{1}$ to compensate for the fact that she was an outsider and still able to approach different networks of speakers.

Even though school and parents remain the primary sources for the transmission of Jèrriais, the dominant use of English weakens the work of school on the Jèrriais population. Jones and Singh (2005) also explored attitudes towards Jèrriais within the community and their questions focused on language preservation and language planning.

The author compared results for the second group of informants (students/young adults in bold characters) in the Gallo study to the results from the Jèrriais study (see Table 1).

Table 1

Comparing Jèrriais and Gallo

\begin{tabular}{|c|c|c|c|}
\hline Questions on preservation and maintenance & \begin{tabular}{|ll}
$\begin{array}{l}\text { "Yes" } \\
(\%)\end{array}$ & answers \\
\end{tabular} & $\begin{array}{ll}\text { "No" answers } \\
(\%)\end{array}$ & \begin{tabular}{|l|} 
“I don’t know” answers \\
$(\%)$
\end{tabular} \\
\hline $\begin{array}{l}\text { (1) Do you think that Jèrriais should be preserved? } \\
\text { Do you think that Gallo should be preserved? }\end{array}$ & $\begin{array}{l}\text { Y } 90 \\
\text { Y } 93.3 \\
\text { Y } 92.9\end{array}$ & N 3.3 (gp1) & $\begin{array}{l}\text { DN } 10^{2} \\
\text { DN7.1 (gp2) }\end{array}$ \\
\hline $\begin{array}{l}\text { (2) Do you think that Jèrriais will be preserved? } \\
\text { Do you think that Gallo will be preserved? }\end{array}$ & \begin{tabular}{|l|l|} 
Y 18 \\
Y 43.3 \\
Y 50
\end{tabular} & \begin{tabular}{|ll} 
N 50 \\
N 36.7 \\
N 14.3 \\
\end{tabular} & $\begin{array}{l}\text { DN } 32 \\
\text { DN } 35.7\end{array}$ \\
\hline $\begin{array}{l}\text { (3) Should there be regular television programs in Jèrriais? } \\
\text { Do you think there should be more television programs in Gallo? }\end{array}$ & $\begin{array}{l}\text { Y } 82 \\
\text { Y } 66.7 \\
\text { Y } 35.7\end{array}$ & N 14.3 & $\begin{array}{l}\text { DN } 10 \\
\text { DN } 30 \\
\text { DN } 50\end{array}$ \\
\hline $\begin{array}{l}\text { (4) Should Jèrriais feature on all the Island's road signs? } \\
\text { Should Gallo appear on all the regional road signs? }\end{array}$ & \begin{tabular}{|l} 
Y 48 \\
Y 43.3 \\
Y 35.7
\end{tabular} & $\begin{array}{l}\text { N } 40 \\
\text { N } 36.7 \\
\text { N } 42.9\end{array}$ & $\begin{array}{l}\text { DN 12 } \\
\text { DN 20 } \\
\text { DN 21.4 }\end{array}$ \\
\hline
\end{tabular}

Generally, there are more positive answers for questions regarding Gallo preservation. Informants from Jones and Singh's study (2005) expressed common positive ideas or feelings concerning the promotion of their language: They are in favor of TV programs and road signs in the local language. In the Gallo community, young speakers do not express any strong feelings towards language promotion and are either indifferent (50\%) or against (42.9\%) the idea of TV programs and road signs in Jèrriais/Gallo. These results confirmed the widespread approval from the community for further actions, the willingness to support inclusion of Jèrriais as part of the school curriculum (introduced in 1999 in elementary schools) and the use of bilingual road signs as an important part of the promotion campaign.

\footnotetext{
1 This technique has a certain degree of randomness due to the method of selection.

${ }^{2} \mathrm{Y}=$ yes, $\mathrm{N}=$ no, $\mathrm{DN}=\mathrm{I}$ do not know, Op = optional.
} 


\section{Will Language Planning Be Successful and Lead to Revitalization?}

School is essential to the promotion of minority varieties as it helps slow down language shift (Jones, 2001, p. 85). Standardization is a necessary step to create a standardized form to teach Gallo in the classroom and facilitate language acquisition. The most important element that governs the success of language revitalization is the approval from the speech community. Jones (2001) explained that "the approval of the indigenous speech community is extremely important in the domain of corpus planning” (p. 88). Increasing the use of Gallo outside of the classroom and creating opportunities to speak it, is the key to successful revitalization. The revitalization movement relies almost always on actively engaged volunteers such as associations, teachers, and individuals who have interest or curiosity for the Gallo culture.

\section{Methods}

\section{Collecting Data: Sources and Building Questionnaires}

This study is based on Boas' framework on the Texas German Dialect Project (Retrieved from http://tgdp.org/index.php) and adapts the sets of questions to the Gallo situation. It is a detailed questionnaire covering the main areas of investigation for the Gallo community: practices, representations, language preservation, and language attitudes and identity.

The framework of the sections on representations and identity allows defining the regional identity more accurately. The informants from both groups answered questions on the relationship between the language and the region: "Is Gallo associated with Brittany?", "Do you think it is necessary to speak/understand Gallo to be a member of the Gallo community?”, “Do you think speaking/understanding Gallo is a good thing?”, or “Do you feel proud to be able to speak/understand Gallo?”. This set of questions gives a general idea of the type of representations expressed by Gallo speakers.

\section{Gallo Identity and Its Representations}

Identity is linked to the language spoken in the region and to the level of competence the speaker reaches in his/her language. Gallo speakers exhibit positive language identity (with a difference between the two groups), but language and identity are not strongly associated and in some cases they are not related at all. Four topics were discussed during the interviews: (1) Gallo is a dialect; (2) perceptions on the language; (3) Gallo identity; and (4) the future of the language. The majority of people interviewed consider Gallo a "dialect” or a "bad variety" of French. Gallo is not considered a language:

"c'est un dialecte, c'est pas une langue.”-“It is a dialect, it is not a language.” (N 11, M, 36:08, La Chapelle Chaussée, 06/08/09); "le gallo en fait, c’est du français déformé c’est tout.”-“Gallo is actually distorted French, that’s it.” (N 11, M, 37:54, La Chapelle-Chaussée, 06/08/09).

Informants mention the feeling of shame at school and the fact that their parents were sometimes speaking patois at home. Informants express a pessimistic opinion about Gallo arguing that older speakers are ashamed of speaking it and refuse to speak it (N 2, M, 10:43, Trans la Forêt, 06/22/09):

“ils vieulent pas rveni a conteu patois ce que ma j'regret profondément.”3_-“They don’t want to go back speaking patois which is what I regret.” (N 2, M, 16:42, Trans la Forêt, 06/22/09).

It is part of the mission of school to promote the idea of a Gallo identity and present the language as a useful communicative tool.

\footnotetext{
${ }^{3}$ Ils (ne) veulent pas recommencer à parler patois ce que je regrette profondément.
} 


\section{Results}

The analysis reflects on the two following questions: (1) How do both groups perceive language preservation efforts?; and (2) Are language and identity intertwined?, How does this affect the speakers' identity?. Both groups of Gallo speakers interviewed express positive reactions towards the preservation of their language. 93.3\% in group 1 and 92.9\% in group 2 answered that Gallo "should be preserved". Undoubtedly, reconstructing Gallo identity through the re-appropriation of culture and language by the community constitutes the main criterion for the success of Gallo maintenance.

The high percent of answers from group 2 manifests a change in mentalities. Generally, students tend to accept their Gallo identity more easily than their parents as they are in the process of learning the language and exposed to the regional culture. During the follow-up interviews, about 10 informants developed an extended answer to describe their Gallo identity and often related it to their region. A few informants expressed positive perceptions of the Gallo language and culture:

"La Haute-Bretagne est aussi importante que la Basse-Bretagne."- "High-Brittany is as important as Lower-Brittany.” (N 10, M, Saint-Père Marc en Poulet, 07/09/09) ${ }^{4}$

Both groups reacted positively to the following representations of Gallo. For question "Is it important to teach Gallo to younger generations?”, the percentage of positive answers was $76.7 \%$ for group 1 and $85.7 \%$ for group 2 (see Figure 1).

Group 1

\section{Group 2}

\section{Do you think it is important to teach Gallo to the younger generations?}
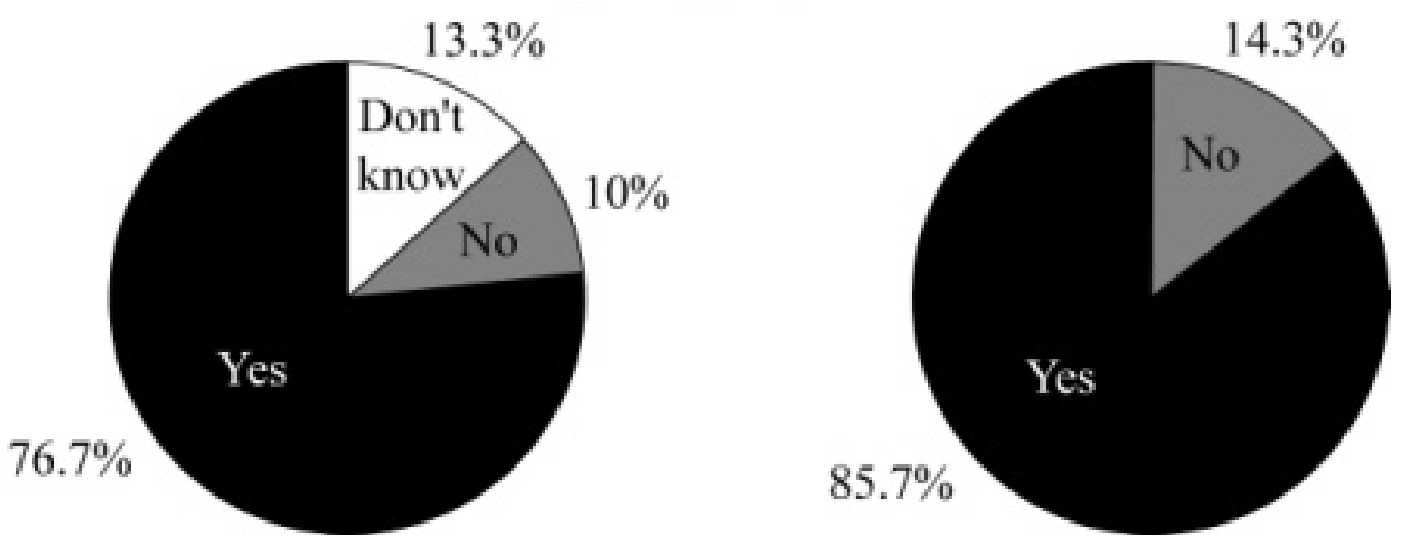

Figure 1. Representations (1).

The importance of language preservation is confirmed by the reactions collected for question "Why is Gallo less spoken/used these days?”. 80\% of group 1 and $92.9 \%$ of group 2 answered that it was due to the lack of transmission. Other factors for the decline of Gallo were evoked such as lingering feelings of shame and the stigmatization of people who speak the regional variety (for $63.3 \%$ of informants in group 1). The idea that Gallo is not a modern language was the third reason mentioned by $64.3 \%$ of informants from the second group (see Figure 2).

\footnotetext{
${ }^{4}$ This interview was not recorded as requested by the informant.
} 
(a)

Do you think Gallo will be preserved?
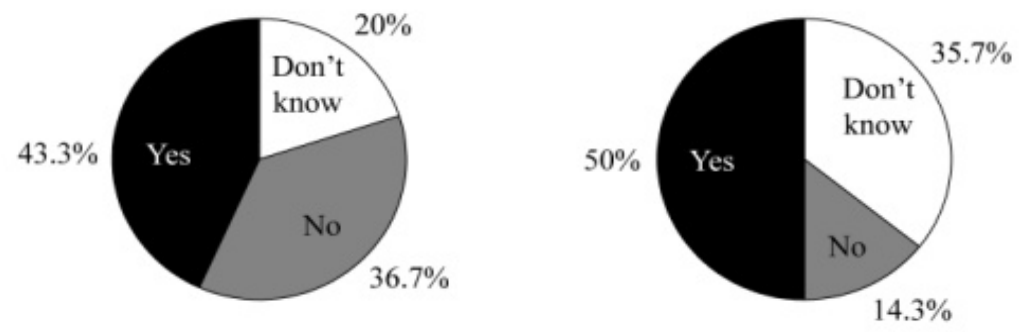

(b)

Do you think it is necessary to speak / understand Gallo to be a member of the Gallo community?
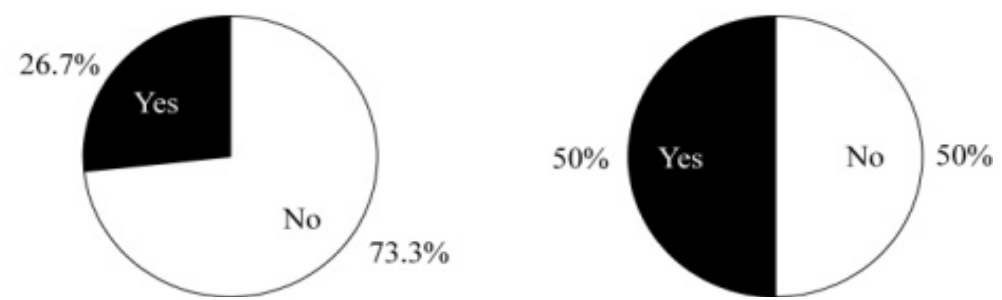

Figure 2. Representations (2).

The association of the two concepts, language and identity, helps rebuild the feeling of an existing Gallo identity that is worth preserving. The ability to speak and/or understand Gallo is not a necessary component of the Gallo identity. Thus, regional and individual identities are separated. For older speakers (group 1) who learned the language with family members and grandparents, Gallo is still associated with stigmatized statements heard at school or within the family environment. The French language was viewed as the only key to economic improvement and social recognition. This category of informants expresses more negative attitudes towards Gallo preservation and stand in an indifferent position towards language planning measures.

Students and young adults (group 2) who learned/are learning Gallo at school appear to be more sensitive to the issue of preservation as they are usually instructed by teachers who are members of language planning associations, as well as researchers and scholars who work with activist groups.

\section{Discussion}

\section{How to Change Language Attitudes}

The findings demonstrate that most of the informants think positively about their region and their language: they believe language transmission is a key to successful language maintenance, although they express realistic reactions to its outcomes.

Like Jèrriais, Gallo is no longer spoken as a native language and a very low number of the population can still speak it fluently (less than 5\% for Gallo and 3.2\% for Jersey). Furthermore, the negative relationship between the language and identity generates a feeling of shame and progressively led to the decline of language use, as it was the case for the Jèrriais language during 19th and 20th centuries. It is noticeable that a significant percent of young Gallo learners feel "Gallo" to some extent or express positive reactions towards the Gallo identity. What constitutes the salient features of the contemporary Gallo identity? 
The modification of perceptions towards the dialect and the creation of a solidarity movement among speakers are some of the elements part of the new identity. Efforts to include "none active" members of the speech community to reshape identity must be reinforced as they usually outnumber the remaining speakers and live within the speech community.

\section{Transmission Is the Key: Different Initiatives for Different Population Groups}

For children, two recent events were organized in the summer 2009 with the initiative of elementary school teachers of Gallo. The first summer camp was devoted to the theme "Amuseriy dans les boés!" 5 for 8 to 12 year-olds in Plumieux, Côtesd'Armor (22). The objective was to discover and practice Gallo, describe nature in the language, and learn about local legends and stories with people from the region. The second summer camp, “Amuseriy a la mé!”, took place in Pleneuf Val André, Côtes d'Armor (22). It was meant for children between the age of 7 and 11. Children learned and practiced Gallo words and expressions while exploring the coast, the beach, and discovering legendary figures of the region.

Data collection helps promoting the language in a different way. The CD released by Chubri in December 2009 on recipes for galettes $^{7}$ or the project realized by the association La Granjagoul ${ }^{8}$ in the summer 2009 on the practices and lexicon of different games of palets ${ }^{9}$ during official tournaments are some examples among others.

Activists recently took strong actions. For instance, the presence of Gallo on road signs, Du galo su lé paniao $^{10}$ was a project launched by a small group of Gallo speakers with the help of mayors from the region. In 2008, in response to the absence of Gallo in several cities of High-Brittany, the CBIL (Coordination Bretagne Indépendante et Libertaire) ${ }^{11}$ decided to place bilingual signs at the entrance of 10 cities in the region of Lamballe and Saint-Brieuc: Saint-Brieuc/St-Berieu, Quessoy/Qhésoué, Yffiniac/Finia, Coëtmieux/Qoémieu, Noyal/Nouia, and Saint-Rieul/St-Rieu. All these efforts and reactions show the active work achieved around the Gallo language. There are several attempts to improve the revitalization techniques. For instance, the association La Granjagoul in the region of Parcé conducted a survey on oral traditions. For the first time, this approach actively seeks the participation of the local population and explicitly expresses the inevitability to save and transmit the Gallo language and culture to younger generations. This method allows the association to meet and exchange with the local speakers, to share local traditions and heritage. This step is an inevitable step to value the regional identity.

\section{Conclusions}

The first result expected from the questionnaires and interviews was the dissociation between the language and regional identity as an expression of non-necessity to speak Gallo to identify oneself as a Breton or as a member of the Breton community. The acknowledgement by younger speakers of their Gallo identity was an unexpected reaction. Although they are not active in the language revitalization process, they are generally in favor of it and present Gallo culture and language as an important part of their identity.

${ }^{5}$ Amusez-vous dans les bois!, Have fun in the woods!

${ }^{6}$ Amusez-vous à la mer!, Have fun at the beach!

7 Breton crêpes.

8 Blend of grange (barn) and goul, sometimes written goull, goule (mouth also the ability to speak).

9 A traditional game played in High-Brittany, equivalent of Bocce ball.

${ }^{10}$ It stands for "Some Gallo on the signs" (Retrieved from http://galo.lautre.net).

${ }^{11}$ Coordination of an Independent and libertarian Brittany. 
To maintain and revitalize an endangered language, it is necessary to rethink the relationship between language and identity to secure its future, and acknowledge the existence of the linguistic variety to facilitate the process of standardization. These stages can only be reached if a dialogue is established between associations, older speakers, learners (adults and children), and neighboring speech communities. Adult learners should get involved in the transmission process with the help of associations along with none-active members of the speech community. Younger learners should be encouraged to participate to the cultural and associative life.

The Gallo language has yet to overcome a few challenges. There is a necessity to develop bilingual and immersion language programs for young learners based for instance on the Breton model. It is also crucial to accept the values and diversity by which the language expresses identity:

"Pour transmettre une identité, ces symboles doivent forcément être très visibles à l'intérieur et à l'extérieur du groupe.” (Jones \& Bulot, 2009, p. 19)—“To transmit identity, these symbols ${ }^{12}$ must inevitably be very visible inside and outside the group".

In the 3rd edition of the Atlas des langues en danger ${ }^{13}$ (Moseley, 2012), the UNESCO (United Nations Educational, Scientific and Cultural Organization) has listed Gallo as a seriously endangered language. It is the first time that Gallo is mentioned in the Atlas, which increases the importance of its maintenance and the maintenance of minority languages in general: "Le gallo est classé 'sérieusement en danger'. Cette fois-ci, l'atlas est présenté sous forme numérique, ce qui permettra des mises à jour régulières.” (Retrieved from www.chubri.org) — “Gallo is classified as 'seriously endangered'.” This time, the atlas is digitalized which will allow regular updates. Other important steps would help Gallo become a fully recognized regional and minority language in France and in Europe: (1) Language planning movement (teachers, educators, associations, and language promoters) must provide a clear and valuable description of the language so that it can progressively detach itself from the stigmatized image and stereotypes it is often subject to; (2) Gallo is related to French and this linguistic and historical relationship must be shown, but the Gallo language and culture should not be restricted to the world of farming; (3) The use of dictionaries, glossaries, and recent publications should make Gallo more public and reduce misunderstanding; (4) There is an urgent need for a standardized form for school materials, language programs, publications, and recognition; and (5) finally, a change in attitudes from the state and French population at large would reinforce its promotion.

In the last few years, the Gallo community has shown a sincere effort to promote the language and has succeeded in introducing the language to a larger audience in Brittany including the western part of the region. The presence of Gallo at school, and the vitality among Gallo speakers and language educators promote the language variety to an inspiration to the neighboring minority language speakers in the process of language preservation.

\section{References}

Blanchet, P., \& Lo Cop, A. (2007). What's new in Gallo? Practices and representations of the language and culture in High-Brittany (Où en est le gallo? Pratiques et représentations de la langue et de la culture en Haute Bretagne). In J.-P. Angoujard \& F. Manzano (Eds.), Around Gallo: Current situation, analyses and perspectives (Autour du Gallo: Etats de lieux, analyses et perspectives: Présentation). Rennes: Presses Universitaires de Rennes.

\footnotetext{
${ }^{12}$ For instance, territory, religion, clothing, customs, and blood.

13 Atlas of Endangered Languages.
} 
Boas, H. (2001). Texas German dialect project. Austin: The University of Texas.

Jones, M. (2001). Jersey Norman French: A linguistic study of an obsolescence dialect. Cambridge: Blackwell.

Jones, M., \& Bulot, T. (2009). Sociolinguistics of the Norman language: Plurality, norms, representations (Sociolinguistique de la langue normande: Pluralité, normes, représentations). Paris: L’Harmattan.

Jones, M., \& Singh, I. (2005). Exploring language change. London \& New York: Routledge.

Moseley, C. (2012). The UNESCO Atlas of the world's languages in danger: Context and process. Cambridge: University of Cambridge.

Nolan, J. S. (2008a). School and extended family in the transmission and revitalisation of Gallo in Upper-Brittany. Journal of Multilingual and Multicultural Development, 29(3), 216-234.

Nolan, J. S. (2008b). The role of Gallo in the identity of Upper-Breton school pupils of the language variety and their parents. Sociolinguistic Studies, 2(1), 131-153. 